\title{
Antibiotic resistant pattern of environmental isolates of Listeria monocytogenes from Ado-Ekiti, Nigeria
}

\author{
David, O. M.* and Odeyemi, A. T. \\ Department of Microbiology, University of Ado-Ekiti, P.M.B. 5363, Ado-Ekiti, Nigeria. \\ Accepted 26 January, 2007
}

\begin{abstract}
Incidence of Listeria monocytogenes in cow manure, agricultural soil, and common vegetables sold in major markets in Ado-Ekiti, Nigeria was determined. Antibiotic resistant pattern of the isolates was examined by paper disk assay. A total of 196 environmental samples were cultured on a selective medium out of which $153(78.1 \%)$ were positive for L. monocytogenes. Erythromycin was the most effective antibiotic against the isolates with the least resistance $(28.1 \%)$ while chloramphenicol proved to be least effective with resistant of $52.29 \%$. The multiple-antibiotic resistant pattern of the isolates showed augumentin/amoxicillin (33.3\%), augumentin/erythromycin (24.18\%), and cotrimoxazole/ chloramphenicol/amoxicillin $(28.8 \%)$ to be most prominent. The least value was observed in cloxacilin/cotrimoxazole/gentamycin with $15.34 \%$. The modal values of the Minimum Inhibitory Concentrations (MICs) of the antibiotics to the isolates range between 4.0 and $>16.0 \mu \mathrm{g} / \mathrm{ml}$. cotrimoxazole and gentamicin recorded the highest MIC compared with other antibiotics.
\end{abstract}

Key words: Listeria monocytogenes, vegetable, cow dung, antibiotic resistance, environmental isolates.

\section{INTRODUCTION}

Listeria monocytogenes, a Gram-positive, rod shaped bacterium, has been reported to be pathogenic for humans and animals (Fleming et al., 1985; Linnan et al., 1988). Recently it has been implicated in several food-borne epidemic listeriosis (Aureli et al., 2000). L. monocytogenes is widely disseminated in the environment: soil, sewage, raw and decaying vegetables (Seeliger and Jones, 1986). The bacterium has a wide reach and prospect to enter food production and processing environment (Rocourt, 1996). L. monocytogenes principally causes meningitides, encephalitis, abortion or septicemia (Nieman and Lorber, 1980; Schuchat et al., 1991). The virulence potential of $L$. monocytogenes has been longestablished in diverse studies (Gellin and Broome, 1989). Swaminathan et al. (1998) reported that a good number, if not all, environmental isolates of $L$. monocytogenes are virulent and express virulence factors only when introduced into animal or human host.

The pathogen can occur as sporadic cases or as farmlands and common vegetables sold in Ado-Ekiti and

\footnotetext{
*Corresponding author. E-mail:davidgenerationng@yahoo.com.
}

epidemics (Schlech et al., 1983); contaminated foods are the principal vehicles of transmission (Schuchat et al., 1991; Mead et al., 1998; CDC, 2000). The rate of reoccurrence of these types of outbreaks is unknown because most cases of $L$. monocytogenes infections are not reported to public health officials (Aureli et al., 2000).

$L$. monocytogenes has been identified to be defiant to environmental stresses including low $\mathrm{pH}$, heat of process (pasteurization), high osmotic pressure and refrigeration temperature $\left(4^{\circ} \mathrm{C}\right)$ (Conner et al., 1986). The pattern of antibiotic susceptibility of $L$. monocytogenes has been reported to be fairly stable for many years (Schald, 1983), though many of the antibiotics are bacteriostatic (Moellering et al., 1972; Wiggins et al., 1978). An upsurge in the antibiotic resistance of $L$. monocytogenes has been previously documented (Peterkin et al., 1991).

Application of faeces or dung slurries of infected (or carrier) animals onto agricultural land as manure can serve as source of the organism (Chukwu et al., 2006; Nicholas et al., 2000). It could be transmitted to healthy animals while browsing and human through contaminated vegetables or fruits (Schlech et al., 1983; Chukwu et al., 2004). This study investigated the incidence of $L$. monocytogenes from ready-to-apply cow dung manure, 
Table 1. Occurrence of Listeria monocytogenes in the studied samples.

\begin{tabular}{|l|c|c|}
\hline \multicolumn{1}{|c|}{ Sample } & Number $^{\star}$ & $\%$ \\
\hline Cow dung $(n=20)$ & 17.00 & 85.00 \\
Soil $(n=36)$ & 32.00 & 91.60 \\
Vegetable $(n=160)$ & 104.00 & 73.75 \\
\hline
\end{tabular}

*Number of samples positive for L. monocytogenes.

soil from vegetable farmlands and common vegetables sold in Ado-Ekiti and the susceptibility of the isolates to antimicrobial agents.

\section{MATERIALS AND METHODS}

\section{Collection of samples}

A total of thirty six soil samples were collected from different vegetable farmlands in Ado-Ekiti $\left(7^{\circ} 40^{\prime} \mathrm{N}, 5^{\circ} 15^{\prime} \mathrm{E}\right)$ and its environs. The samples were collected in separate sterile bottles and stored in an ice pack. Twenty ready-to-apply cow manures were collected at different vegetable farmlands into sterile bottles and kept in ice pack. Forty samples of each of the four vegetables (Amarathus cruetus L, Sencecio biafrae Oliy and Hien, Talinum fruiticosum Jacq, and Telfairia occidentalis Hook F) were also purchased from four different markets; Oja-Oba, Mojere, Irona and Enu-odi all in Ado-Ekiti, Nigeria. The vegetables were collected in a new, sterile polythene bags. The vegetables were later identified and authenticated in the Herbarium Unit of the Department of Plant Science and Forestry, University of Ado-Ekiti, Nigeria. The samples were transported to the laboratory for immediate microbial analysis.

\section{Processing of samples}

The primary enrichment test was carried out by inoculating one gram of each of the samples (soil and cow dung) into $9.0 \mathrm{ml}$ of Listeria Selective broth (LSB) (Fluka) and incubated at $30^{\circ} \mathrm{C}$. After $24 \mathrm{~h}, 0.1 \mathrm{ml}$ of the enrichment culture was plated on Tryptic Soy Agar (TSA) (Oxoid) supplemented with $1.00 \mathrm{~g} / \mathrm{l}$ esculin and $5.00 \%$ human blood. The method of Blakeman (1981) was used to isolate $L$. monocytogenes from surface of the vegetables. The isolates were identified and authenticated on the bases of their biochemical reactions as described by Olutiola et al. (2001). The results were interpreted according to Seelinger and Jones (1986).

\section{Antibiotic sensitivity test}

The antibiotic sensitivity of the isolates was determined by the disk diffusion method of CLSI (2005) on Mueller- Hilton agar. The following antibiotics (Difco) amoxicillin $(25 \mu \mathrm{g})$, augmentin $(3 \mu \mathrm{g})$, chloramphenicol $(30 \mu \mathrm{g})$, cloxacillin $(5 \mu \mathrm{g})$, cotrimoxazole $(25 \mu \mathrm{g})$, erythromycin $(5 \mu \mathrm{g})$, gentamicin $(10 \mu \mathrm{g})$, and tetracycline $(10 \mu \mathrm{g})$. The inoculum was standardized by adjusting its density to equal the turbidity of a barium sulphate $\left(\mathrm{BaSO}_{4}\right)$ which is the $0.5 \mathrm{McF}$ arland turbidity standard, and incubated at $35^{\circ} \mathrm{C}$ for $18 \mathrm{~h}$. The diameter of the zone of clearance (including the diameter of the disk) was measured to the nearest whole millimeter and interpreted on the basis of CLSI guideline (CLSI, 2005).

Determination of the results of Minimum Inhibitory Concentration (MIC) and Minimum Bactericidal Concentration (MBC) were done according to the method of Stroke and Ridgway (1980). The turbidity of the inocula was adjusted to match that of $0.5 \mathrm{McF}$ arland standards. The tubes were incubated in air at $35^{\circ} \mathrm{C}$ for $16 \mathrm{~h}$ and later observed for microbial growth.

\section{RESULTS AND DISCUSSION}

The identification of the isolates was based on cultural and morphological appearances. The identity of the isolates was further confirmed by biochemical tests. The results were interpreted according to Seelinger and Jones, (1986). The results of this study revealed that the pathogen was present in the samples investigated; cow dung, agricultural soil, and vegetables. It was observed that the vegetables from Enu-Odi Market had the highest occurrence of the pathogen and Amarathus cruetus among the four vegetables showed highest incidence of L. monocytogenes (Table 1). Table 2 shows the in vitro resistance of the isolates to common antibiotics. Chloramphenicol appeared to be most ineffective. $52.29 \%$ of the isolates were resistant to it. This is followed by augmentin. The isolates had the highest resistance to cloxacillin. Schald (1983) had earlier reported that $L$. monocytogenes isolates are susceptible to chloramphenicol and gentamicin. Environmental factors like previous exposure, the type of antibiotic used in the respective locality, and incidence of plasmids in the isolates may have resulted to the antibiotics resistance. This has been found in several isolates of $L$. monocytogenes (Hadorn et al., 1993; Yutaka et al., 2004). Such plasmid could be pheromones-responsible or broad-host-range (Rice et al., 1995). The resistance to antibiotic can also be as a result of the selective antibiotic pressure (Khachatouarians, 1998; Patricia and Wootan, 1998; Hanchun et al., 2004) or integrons and other insertion elements (Didier et al., 2000).

The number of resistant strains from the cow dung ranges from $41.18-70.59 \%$ (Table 3 ). This could be a resultant effect of the routinely administration of the sublethal antibiotic doses to the cows to increase the growth rate and reduce the amount of the feeds required to raised the animals to the slaughter size (Patricia and Wootan, 1998; Witte, 1998).

Vegetables have been reported to be a major vehicle for the transmission of the $L$. monocytogenes (Seelinger and Jones, 1986). The vegetables examined showed the presence of the organism. This finding corroborates the report of Österbald et al. (1999) that vegetables can harbor antibiotic resistant organisms.

Multiple antibiotic resistances of $L$. monocytogenes isolated from environmental sources are summarized in the Table 3. Eight different antibiotic resistance patterns were observed in the study. The patterns were different to the ones observed by Moellering et al. (1972). The changes may be as a result of the genetic modification and/or selective pressure of the antibiotics. Multiple resistant bacterial strains (like the ones observed in this study) could be transmitted to human either through contact or consumption (Hanchun et al., 2004). This may further complicate the clinical management of disease caused by the pathogen and the resistance could be transferred to other (related) organisms (Brooks et al., 2001). 
Table 2. Distribution (\%) of $L$. monocytogenes in vegetables sold in major markets in Ado-Ekiti.

\begin{tabular}{|l|c|c|c|c|}
\hline \multirow{2}{*}{ Vegetable } & \multicolumn{4}{|c|}{ Locations (Markets) } \\
\cline { 2 - 5 } & Enu-Odi & Irona & Mojere & Oja-Oba \\
\hline A. cruetus & 88.8 & 50.0 & 36.4 & 62.5 \\
S. biafrae & 90.0 & 88.8 & 42.9 & 42.9 \\
T. fruiticosum & 66.6 & 75.0 & 72.7 & 83.3 \\
Te. occidentalis & 77.8 & 50.0 & 40.0 & 45.5 \\
\hline
\end{tabular}

Table 3. In vitro antibiotic resistance of environmental isolates of $L$. monocytogenes.

\begin{tabular}{|l|c|c|c|c|c|c|c|c|}
\hline \multirow{2}{*}{\multicolumn{1}{|c|}{ Antibiotics }} & \multicolumn{2}{|c|}{ Cow manure } & \multicolumn{2}{c|}{ Soil } & \multicolumn{2}{c|}{ Vegetables } & \multicolumn{2}{c|}{ Total } \\
\cline { 2 - 9 } & $\mathbf{n = 1 7}$ & $\%$ & $\mathbf{n = 3 2}$ & $\%$ & $\mathbf{n = 1 0 4}$ & $\%$ & $\mathbf{n}=\mathbf{1 5 3}$ & $\%$ \\
\hline Amoxicillin $(25 \mu \mathrm{g})$ & 9.0 & 52.94 & 9.0 & 28.13 & 37.0 & 35.58 & 55.0 & 35.95 \\
Augmentin $(5 \mu \mathrm{g})$ & 8.0 & 47.06 & 14.0 & 43.75 & 38.0 & 36.54 & 60.0 & 39.72 \\
Chloramphenicol $(30 \mu \mathrm{g})$ & 11.0 & 64.71 & 9.0 & 28.13 & 60.0 & 57.69 & 80.0 & 52.29 \\
Cloxacillin $(5 \mu \mathrm{g})$ & 7.0 & 41.18 & 11.0 & 34.36 & 21.0 & 20.19 & 39.0 & 25.49 \\
Cotrimoxazole $(25 \mu \mathrm{g})$ & 12.0 & 70.59 & 13.0 & 40.63 & 30.0 & 28.85 & 55.0 & 35.95 \\
Erythromycin $(5 \mu \mathrm{g})$ & 8.0 & 47.06 & 12.0 & 37.50 & 23.0 & 22.12 & 43.0 & 28.10 \\
Gentamicin $(10 \mu \mathrm{g})$ & 10.0 & 58.82 & 16.0 & 50.00 & 33.0 & 31.73 & 59.0 & 38.56 \\
Tetracycline $(10 \mu \mathrm{g})$ & 9.0 & 52.94 & 11.0 & 34.36 & 32.0 & 30.77 & 52.0 & 33.99 \\
\hline
\end{tabular}

The data are the modal values of three determinations.

Table 4. The Minimum Inhibitory Concentrations (MICs) of selected antibiotics against environmental isolates of $L$. monocytogenes $(\mu \mathrm{g} / \mathrm{ml})$.

\begin{tabular}{|l|c|c|c|}
\hline \multicolumn{1}{|c|}{ Antibiotics } & Cow manure & Soil & Vegetables \\
\hline Amoxicillin & 8.0 & 8.0 & 4.0 \\
Augmentin & 4.0 & 16.0 & 16.0 \\
Chloramphenicol & 16.0 & 8.0 & 16.0 \\
Cloxacillin & 8.0 & 16.0 & 8.0 \\
Cotrimoxazole & 16.0 & $>16.0$ & 16.0 \\
Erythromycin & 8.0 & 16.0 & 8.0 \\
Gentamicin & $>16.0$ & 16.0 & 16.0 \\
Tetracycline & 8.0 & 16.0 & 4.0 \\
\hline
\end{tabular}

The data are the modal values of three determinations.

The minimum inhibitory concentrations (MICs) and multiple-antibiotic resistant pattern of the isolates were shown in Tables 4 and 5. A total of 51 isolates (33.3\%) were resistance to the combination of augumentin and amoxicillin while augumentin/erythromycin had $24.18 \%$. The cotrimoxazole/chloramphenicol/amoxicillin resistance isolates were $28.8 \%$. The least value $(n=25)$ was observed in cloxacilin/cotrimoxazole/gentamycin with $15.34 \%$. The modal values of the Minimum Inhibitory Concentrations (MICs) of the antibiotics to the isolates range between 4.0 and $>16.0 \mu \mathrm{g} / \mathrm{ml}$. cotrimoxazole and gentamicin recorded the highest MIC compared with 
Table 5. Multiple antibiotic resistances in environmental isolates of $L$. monocytogenes.

\begin{tabular}{|c|c|c|c|c|c|c|c|}
\hline \multirow{2}{*}{ Antibiotics } & \multicolumn{2}{|c|}{ Cow manure } & \multicolumn{2}{|c|}{ Soil } & \multicolumn{2}{c|}{ Vegetables } & Total \\
\cline { 2 - 8 } & $\mathbf{n = 1 7}$ & $\%$ & $\mathbf{n = 3 2}$ & $\%$ & $\mathbf{n = 1 0 4}$ & $\%$ & $\%$ \\
\hline Aug. + Ery. & 3.0 & 17.7 & 9.0 & 28.1 & 25.0 & 24.1 & 24.2 \\
Aug. + Amx. & 5.0 & 29.4 & 11.0 & 34.4 & 35.0 & 33.7 & 33.3 \\
Ery. + Tet. & 2.0 & 11.8 & 9.0 & 28.1 & 16.0 & 1549 & 17.7 \\
Clx. + Gen. & 6.0 & 32.3 & 8.0 & 25.0 & 20.0 & 19.2 & 22.2 \\
Cot + Chl. & 4.0 & 23.5 & 5.0 & 15.6 & 25.0 & 24.0 & 22.2 \\
Aug. + Ery. + Tet & 1.0 & 5.9 & 3.0 & 9.4 & 30.0 & 28.9 & 22.2 \\
Clx. + Cot. + Gen. & 3.0 & 17.6 & 9.0 & 28.1 & 13.0 & 12.5 & 15.3 \\
Cot. + Chl. + Amx. & 2.0 & 11.8 & 10.0 & 31.3 & 32.0 & 30.8 & 28.8 \\
\hline
\end{tabular}

Amx $=$ Amoxicilin $(25 \mu \mathrm{g})$

Aug $=$ Augumentin $(5 \mu \mathrm{g})$

$\mathrm{Chl}=$ Chloramphicol $(30 \mu \mathrm{g})$

$\mathrm{Clx}=$ Cloxacilin $(5 \mu \mathrm{g})$

Cot $=$ Cotrimoxazole $(25 \mu \mathrm{g})$

Ery $=$ Erythromycin $(5 \mu \mathrm{g})$

Gen $=$ Gentamycin $(10 \mu \mathrm{g})$

Tet $=$ Tetracycline $(10 \mu \mathrm{g})$

other antibiotics. Similar trends of antibiotic resistance were also noticed by Khachatourians (1998), Schlech (1983).

Antibiotic resistance has attained a critical stage in the human medicine. The findings of this study show that cow dung, mainly used as manure in vegetable farmlands, soil, and vegetables sold in the markets could be sources of $L$. monocytogenes. The usage of antibiotics for sub-therapeutic purpose in animals especially cow should be totally discouraged. Also vegetables should be painstakingly washed and pickled before eating, and manure thoroughly processed before application.

\section{REFERENCES}

Aureli P, Fiorucci GC, Caroli D, Machiaro B, Novaro O, Leone L, Salmoso S (2000). An outbreak of febrile gastroenteritis associated with corn contaminated by Listeria monocytogenes. N. Engl. J. Med. 342: 1236-1241.

Blakeman JP (1981). Microbial ecology of the phylloplane. Academic Press London pp. 502.

Brooks GF, Butel SJ, Moorse AS (2001). Jawetz Melnic and Aldelberg's Medical Microbiology. $22^{\text {nd }}$ edn John-Wiley and Son London.

CDC (2000). Diagnosis and Management of food-borne illness. A primer for Physicians. MMWR, 50: 20-22.

Chukwu OOC, Ogbonna CIC, Muhammad MJ, Olabode OA, Nwobu O, Ogo IN, Makinde AA, Elam HE, Okewole PA (2004). Listeria monocytogenes and other Listeria species in poultry faeces applied as manure on farm lands: Environmental and food safety. Niger. J. Biotechnol. 15(1): 52-59.

Chukwu OOC, Ogbonna CIC, Olabode OA, Chukwu DI, Owuliri FC, Nwankiti OO (2006). Listeria monocytogenes in Nigerian processed meats and ready-to-eat dairy products. Niger. J. Microbiol. 20(2): 900-904.

CLSI (2005). Performance standards for antimicrobial susceptibility testing; fifteenth informational supplement, M100-S15, vol. 25, no. 1. Clinical and Laboratory Standards Institute Wayne, Pa.

Conner DE, Brackett RE, Beuchat LR (1986). Effect of temperature sodium chloride and $\mathrm{pH}$ on the growth of Listeria monocytogenes in cabbage juice. Appl. Environ. Microbiol. 52(1): 59-62.

Didier M, Broderich D, Vera AW, Julian D (2000). Antibiotic resistance in the ECOR collection :Intergrons and identification of a novel Genes. Antimicrob. Agents Chemother. 15: 1568-1574.

Fleming DW, Cochi SL, MacDonald KL, Browdum J, Hayes PS, Plikaytis BD, Holmes MB, Audurier A, Broome CV, Reingold AL (1985). Pasteurized milk as a vehicle of infection in an outbreak of listeriosis. N. Engl. J. Med. 312: 404-407.

Gelli BG, Broome CV (1989). Listeriosis, J. Am. Med. Assoc. 261: 13131320.

Hanchun Y, Sheng C, David GW, Shaohua Z, Patric MD, Robert W, Jianghong $M$ (2004). Characterization of multiple antimicrobialresistant Escherichia coli isolates from chicken and swine in China. J. Clin Microb. 42: 3484-3489.

Hadorn K, Hachlor H, Scherffner A, Kayser FA (1993). Genetic characterization of plasmid-encoded multiple antibiotic resistance in a strain of Listeria monocytogenes causing endocarditis. Eur. J. Clin. Microbiol. Infect. Dis. 12: 928-937.

Khachatourians GG (1998). Agricultural use of antibiotic resistant bacteria. Can Med. Ass. J. 159 (9): 1129-1136.

Linnan MJ, Mascola L, Lou XD, Goulet V, May S, Salminen C, Hird DW, Yonekura ML, Hayes P, Weaver R, Audurier A, Plikaytis BD, Fannin SL Kleks A, Broome CV (1988). Epidemic listeriosis associated with an-style cheese. N. Engl J. Med. 319: 823- 828.

Mead PS, Slustker L, Dietz V, Bresee J (1998). Food-Epidemic related illness and the death in the United State. Emmerg. Infect. Dis., 5 (5): 607-625.

Moellering RC, Medoff G, Leech I, Wennersten C, Kunz LJ (1972). Antibiotic synergism against Listeria monocytogenes. Antimicrob. Agents Chemother. 1: 30-34.

Nicholas FA, Hutchin ML, Smith KA (2000). A study of farm manure applications to agricultural land and an assessment of the risk of pathogen transferinto the food chain. Research Report. Ministry of Agriculture, Fisheries and Food, UK.

Nieman RE, Lober E (1980). Listeriosis in adult, a changing pattern report of 8 cases and a review of the literature 1963-978. Rev. Infect. Dis. 2:207-227.

Olutiola PO, Famurewa O, Sonntag HG (2001). An introduction to General Microbiology A practical approach. Heiderberger Vserlagsutst and Druckerel Heidelberg. pp. 122-132.

Österbald M, Ponsak O, Peterzens M, Heleninsa H, Honvinen P (1999). Antimicrobial susceptibility of Enterobacteriaceae isolated from vegetables. J. Antimicrob. Chemother. 43: 503-509.

Patricia BL, Wootan GM (1998). Protecting the jewels of medicine : A strategic plan topreservev the effectiveness of antibiotics. Available on line URL: http:// www.cspinet.org

Peterkin PI, Idziak ES, Sarpe AN (1991). Detection of Listeria monocy- 
togenes direct colony hybridization on hydrophobic grid-membrane by using chromogen-labelled DNA probe. Appl. Environ. Microb. 57: 586-591.

Rice EW, Messer JW, Johnson CH, Reasoners DJ (1995). Occurrence of high-level-aminoglycoside resistance in environmental isolates of Enterococus. Appl. Environ. Microbiol. 61: 374-375.

Rocourt JP (1996). Genome finger printing of International typing study of Listeria monocytogenes via pulse-field gel (PFGE) Int. J. Food Microb. 32: 343-355.

Schald WM (1983). Evaluation of rifampin and other antibiotics against Listeria monocytogenes in vitro and in vivo. Rev. Infect. Dis. 5 (Suppl. B) S593-S599.

Schlech WF (1983) Evaluation of rivampin and other antibiotic against Listeria monocytogenes in vitro and in vivo. Rev. Infect. Dis. 5 (Suppl. 3): S593-S599.

Schlech WF, Lavigne PM, Bortolussi RA (1983). Epidemic listeriosis-evidence for transmission by food. N. Engl. J. Med. 308: 203-206.

Seelinger HPR, Jones D (1986). Genus Listeria. In: Sneath PHA, Mair HS, Sharp ME, Hold JG (Ed). Bergey Manual of Systematic Bacteriology Vol. 2. The Williams and Wilkins Co. Baltimore.

Stroke EJ, Ridgway GL (1980). Clinical Bacteriology. $5^{\text {th }}$ edn Edward Arnold London. p. 234.
Schuchat A, Swaminathan B, Broome CV (1991). Epidemiology of human listeriosis Clin. Microbiol. Rev. 4: 169-183.

Swaminathan B, Rocourt J, Jacques B (1998). Listeria. In: Manual of Clinical Microbiology. $6^{\text {th }}$ Edn. ASM Washinton DC

Wiggins GL, Albritton WV, Feeley JC (1978). Antibio0tic susceptibility of Clinical isolates of Listeria monocytogenes. Antimicrob. Agents Chemother. 12: 854- 860.

Witte W (1998). Medical consequences of antibiotics used in agriculture. Science. 274: 996-997.

Yutaka S, Naohira S, Yohei D, Yoshichika A (2004). Escherichia coli producing CTX-M-2 beta-lactamase in cattle in Japan. Emerg. Infect. Dis. 10 (1): 69-75. 